\title{
Cambridge
}

Pulpits, Politics and Public Order in England, 1760-1832

\section{ROBERT HOLE}

Religion and politics have always maintained a close, but turbulent relationship. This new book examines the ways in which the social upheaval of the years 1760-1832 affected Christian political beliefs and how the church was used as a means of maintaining public order and control during a time of great unrest.

E32.50 net HB $0521364868352 \mathrm{pp}$.

\section{The Europe of the Devout}

The Catholic Reformation and the Foundation of a New Society LOUIS CHATELLIER

Translated by JEAN BIRRELL

Louis Chatellier examines the religious and social changes that followed the Council of Trent in 1563. By examining the Marian Congregations as an example of lay devotion, he is able to describe the wider process of modernisation which was sweeping Europe.

E27.50 net HB $0521363330288 \mathrm{pp}$.

Past and Present Publications

Co-published with the Maison des Sciences de I'Homme, Paris

\section{Roman Canon Law in Reformation England}

\section{R. H. HELMHOLZ}

Clearly and elegantly written this book draws on court records and the English common-law system to demonstrate the extent to which, contrary to received wisdom, Roman canon law survived in England after the upheavals of the Protestant Reformation.

E25.00 net $H B \quad 0521381916 \quad 240 \mathrm{pp}$.

Cambridge Studies in English Legal History

\section{Between the Times}

The Travail of the Protestant Establishment in America, 1900-1960

\section{Edited by WILLIAM R. HUTCHINSON}

Twelve historians discuss the nature of the Protestant establishment and its response to the pluralism of modern society. Contributions come both from inside the establishment and from impartial observers all of whom consider this period as of vital importance in the evolution of the church.

$£ 35.00$ net HB $0521361680 \quad 340 \mathrm{pp}$.

Religion and American Public Life

\section{Lordship and the Urban Community}

Durham and its Overlords, $1250-1540$

MARGARET BONNEY

Though geographically removed from the centre of power in medieval times, Durham had great strategic and ecclesiastical importance. Margaret Bonney traces the city's development and three aspects of the relationship between the townsmen and their overlords: finance, the economy and law and order.

£30.00 net HB $0521362873321 \mathrm{pp}$.

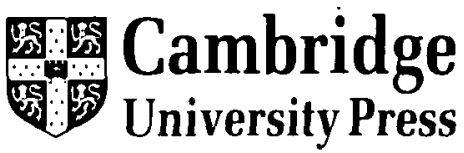

The Edinburgh Building, Cambridge CB2 2RU, UK. 


\section{MICROFORMS ON ECCLESIASTICAL HISTORY \\ - FOR UNIVERSITIES, COLLEGES \& LIBRARIES •}

MEDIAEVAL MANUSCRIPTS $\bullet$ QUAKER $\bullet$ C. of E. RECORDS TRACTARIAN • PERIODICALS • SPG • SPCK FOR FREE NEW BROCHURE RETURN THIS SLIP

$\square$ Please send me your free Religious History brochure

$\square$ Please add my name to your regular mailing list FROM: DATE: 
Armogathe (ed.), Le Grand Siècle et le Bible: by W. R. Ward

Signorotto, Inquisitori e mistici nel Seicento italiano. L'eresia di Santa Pelagia; Martin, Witchcraft and the Inquisition in Venice, 1550-1650: by Peter Burke

Grell, Dutch Calvinists in Early Stuart London: the Dutch church in Austin Friars 1603-1642: by Alastair Hamilton

Lynch, Bourbon Spain. 1700-1808: by Raymond Carr

Hatch, The Democratization of American Christianity: by Richard Carwardine

Urry, None but Saints. The transformation of Mennonite life in Russia 1789-1889: by Jonathan Shepard

Cashdollar, The Transformation of Theology, 1830-1890. Positivism and Protestant thought in Britain and America: by Boyd Hilton

Saarinen, Gottes Wirken auf uns. Die tranzendentale Deutung des Gegenwart-Christi-Motivs in der Luthezforschung: by Alister McGrath

Sagovsky, 'On God's Side'. A life of George Tyrrell: by Owen Chadwick

della Salda, Obbedienza e Pace. Il vescovo A. G. Roncalli fra Sofia e Roma 1925-1934: by Peter Hoffmann

Symonds, Alternative Saints. The post-Reformation British people commemorated by the Church of England: by Peter Newman Brooks

Nolan and Nolan, Christian Pilgrimages in Modern Western Europe: by W.J. Sheils

Grane and Horby (eds), The Danish Reformation against its International Background: by Geoffrey Elton

McLelland and Duffield (eds), The Life, Early Letters and Eucharistic Writings of Peter Martyr: by Peter Newman Brooks

Biersack, Initia Bellarminiana : by A. D. Wright

Doree (ed.), The Parish Register and Tithing Book of Thomas Hassall of Amwell: by W. J. Sheils

Rose, Haddenham Quaker History $1600-1870$ : by Geoffrey F. Nuttall

van den Berg, The Idea of Tolerance and the Act of Toleration: by John Miller

Barnard, John Potier: by Stephen Taylor

Nurser, The Reign of Conscience: by Edward Acton

Vecchio, Politica e democrazia nelle riviste poplari (1919-1926): by H. Hearder

Besier (ed.), Die Mittwochs-Gesellschaft im Kaiserreich: by Owen Chadwick

\section{AUTHORS' ADDRESSES}

Dr Peter Jackson, Department of History, University of Keele, Keele, Staffordshire $\mathrm{ST}_{5} \mathrm{5}_{\mathbf{B G}}$

Dr Margaret Harvey, Department of History, University of Durham, 43-46 North Bailey, Durham DHI $3 \mathrm{EX}$

Dr G. M. Ditchfield, Faculty of the Humanities, Darwin College, The University, Canterbury, Kent CT2 $7 \mathrm{NY}$

Professor G. I. T. Machin, Department of Modern History, University of Dundee DD $1{ }_{4} \mathrm{HN}$

Mr Jan van den Berg, P O Box 363,5340 A J, Oss, Netherlands 


\section{Contents}

A RTILES

The Crusade Against the Mongols (1241), by Peter Jackson

An Englishiman at the Roman Curia during the Council. of Basle: Andrew Holes, his SERzoN of 1433 AND hIS BoOKs, BY MArgaret Harvey

Anti-Trinttakianisu and Toleration in Late Eighteenth Century British Politics: the Unitarian Petition of i792, by G. M. Ditchfield

Markiage and the Churches in the ig3os: Royal abdication and Divorce Refore, 1936-7, BY G. I. T. MACHIN

\section{NOTES AND DOCUMENTS}

Thomas Morgan versus William Warburton: A Conflict the Other Way Round, by JAN VAN DEN BERG

Braun and Gilomen (eds), Helvetia Sacra. I/6: Arcidiocesi e Diocesi VI. La Diocesi di Como. L'Arcidiocesi di Gorizia. L'Administrazione Apostolica Ticinese, poi Diocesi di Lugane. L'Arcidiocesi di Milano: by Geoffrey F. Nuttall

Neusner and others (eds), The Social World of Formative Christianity and Judaism. Essays in tribute to Howard Clark Kee; Segal, Rebecca's Children. Judaism and Christianity in the Roman World: by Judith M. Lieu

Maier, Le Dossier du Donatisme. I: Des origines à la mort de Constance II (303-36r). II: De Julien 'Apostat à Saint Jean Damascène $(36 r-750)$ : by W. H. C. Frend

Wybrew, The Orthodox Liturgy. The development of the eucharistic liturgy in the Byzantine rite: by Michael Angold

Burns (ed.), The Cambridge History of Medieval Political Thought, c. 350-c. 1450: by George Garnett

Ennen, The Medieval Woman: by Shulamith Shahar

Saint-Roch (ed.), Liber Sacramentorum Engolismensis. Manuscrit B.N. Lat. 816. Le Sacramentaire Gelasien dPAngoulême; Liber Sacramentorum Engolismensis: by Janet L. Nelson

McKitterick, The Carolingians and the Written Word: by Roger Collins

Schamper, S. Bénigne de Dijon. Untersuchangen zum Necrolog der Handschrift. Bibl. mun. de Dijon, ms. 634 : by H. E. J. Cowdrey

Ridyard, The Royal Saints of Anglo-Saxon England. A study of West Saxon and East Anglian cults: by C. P. Wormald

E. Gordon Whatley, The Saint of London. The life and miracles of St Erkenwald. Text and translation: by $\mathbf{R}$. C. Love

Mason (ed.), Westminster Abbey Charters 1066-c. 1214: by Gervase Rosser

Burton (ed.), English Episcopal Acta. V: York 1070-1r54: by Barrie Dobson

Morenzoni, Thomas de Chobham. Summa de arte praedicandi: by D. L. D'Avray

Swanson, John of Wales. A study of the works and ideas of a thirteenth-century friar: by Conrado Guardiola

Lee, Reeves and Silano (eds), Western Mediterrancan Prophecy: the school of Joachim of Fiore and the fourteenth-century Breviloquium: by Robert E. Lerner

Ogilvie-Thomson (ed.), Richard Rolle: Prose and verse edited from MS Longleat 29 and related manuscripls: by Barry Windeatt

Flynn, Sacred Charity. Confraternities and social zelfare in Spain, 1

Wittlin (ed.), Francesc Eiximenis. Psalterium alias Laudatorium Papae Benedicto XIII dedicatum: by R: Brian Tate

Mynors (trans.), The Correspondence of Erasmus. Letters 1252 to 1355,1522 to 1523 : by Geoffrey F. Nuttall

Ozment, Religion and Culture in the Renaissance and Reformation: by Miri Rubin

Whiting, The Blind Devotion of the People. Popular religion and the English Reformation: by Peter Heath

Helmholz, Roman Canon Lazw in Reformation England: by Geoffrey Elton

Scribner, Popular Culture and Popular Movements in Reformation Germany; Wright, Capitalism, the State and the Lutheran Reformation. Sixteenth-century Hesse: by Tom Scott

Gritsch, Thomas Müntzer. A tragedy of errors; Scott, Thomas Mintzer. Theology and revolution in the German Reformation: by Euan Cameron

Parente, Religious Drama and the Humanist Tradition. Christian theater in Germany and in the Netherlands: by Dominic Baker-Smith 